\title{
THE OPTIMIZATION OF RURAL LANDSCAPE IN THE LIGHT OF THE IDEA OF SUSTAINABLE DEVELOPMENT - THE EXAMPLE OF POLAND
}

\author{
Michą Sobala, Urszula Myga-Piątek \\ Department of Regional Geography and Tourism, University of Silesia, Sosnowiec, Poland
}

Manuscript received: May 12, 2016

Revised version: August 11, 2016

\begin{abstract}
Sobala M., Myga-Piątek U., 2016. The optimization of rural landscape in the light of the idea of sustainable development - the example of Poland. Quaestiones Geographicae 35(3), Bogucki Wydawnictwo Naukowe, Poznań, pp. 61-73, 3 figs, 2 tables.

AвSTRACT: Contemporary rural landscapes in Poland are being changed intensively and adversely. These changes lead to landscape disharmony, spatial disorder, the blurring of individual and specific features and disruption to the ecological equilibrium. This article aims to present general rules for the optimization of rural landscapes. It discusses the causes and consequences of unfavourable changes within Poland's rural landscapes which constitute a threat to their sustainable development. The authors attempt to identify the major factors to be considered in taking steps aimed at landscape optimization. Landscape equilibrium may be assessed through the sustainable development dimensions: ethical, ecological, social, economic, technical, political and legal. Landscape optimization consists in maintaining the balance within these dimensions.
\end{abstract}

KEY WORDS: rural landscapes, landscape optimization, sustainable development, rural heritage

Corresponding author: Michat Sobala (e-mail: m-sobala@wp.pl)

\section{Introduction}

Rural landscapes are the most common type of landscapes in Poland. This fact results largely from environmental preconditions $(71 \%$ of Poland's area comprises lowlands), as well as cultural ones (since World War II, Poland's rural population has accounted for $70 \%$ of the total population). Rural landscapes include landscapes of agricultural use and settlement landscapes. The background of rural landscapes includes areas of agricultural use (arable land, meadows and pasture land) and temporarily idle or waste land. Rural landscapes in Poland are composed of fields of various area and their size, shape and arrangement are often a characteristic feature of a particular region (patchwork fields, large-area fields, etc.), which are evidence of old well-established ways of land management. Within the fields, there are frequently other forms of land cover, including groves, reservoirs, swampy wasteland, tree clumps, overgrown boundary strips and field shrubs. They add distinctive colours to the physiognomy of rural landscapes and are often their distinguishing features (landscape landmarks) (Myga-Piątek et al. 2015). The background of rural landscapes, in its broad sense, includes villages and locations of various size and topography. The structure and morphology of rural settlements are characteristic features of 
particular regions in Poland and may be analyzed in terms of typology, e.g. linear settlements, forest villages, row villages, circular villages, rundlings, fork-road villages, localities etc. (Chmielewski et al. 2015). In the past, rural settlements were established according to Polish or German law, with highly regular building arrangements and land division, as well as the Russian and Vlach law, with characteristic building arrangements concentrated in lowlands or dispersed in mountainous regions, with large distances between particular courts (Bogdanowski 1998, Angiel, Pietrzak 2009).

Rural landscapes in Poland developed for centuries and, as such, they constituted a 'long-lasting form' (Bański 2009). In this sense, they were the carriers of multiple values (old age, durability, authenticity, historic features, symbolics, genius loci, sacrum, aesthetic and emotional values). The physiognomy and semiotics of rural landscapes are still a characteristic form which distinguish Poland from its neighbouring countries. Landscapes have undergone evolutionary or, less often, revolutionary changes as a result of simultaneous factors, mainly natural ones (soil quality, water relations, climatic conditions, surface features and hypsometry), but also others cultural preconditions. The strongest influences were those related to social and property matters (including the decline of feudalism, granting property rights to peasantry), law and administration (land reforms), history and politics (nationalization, privatization), technological and civilizational development (including the modernization of agriculture and countryside or the industrialization of production), economy (including the commercialization of agriculture, the economic situation, subsidies from the government and, recently, from the European Union). Moreover, cultural-ethnic conditions (traditional methods of land management, adjusted to environmental conditions, architectonic regionalism) played an important role. Even though rural landscapes are the type which is best adapted to environmental conditions, they seldom developed in an optimum way, without a threat to environmental sustainability (Sobala 2015).

This article aims to present general rules for the optimization of rural landscapes. It discusses the causes and consequences of unfavourable changes within rural landscapes in Poland, which constitute a threat to their sustainable development. Furthermore, the authors attempt to point to the major factors which should be considered in steps aimed at landscape optimization.

The authors presume that the process of landscape optimization is preconditioned by its rational use and consists in balancing:

- the ecological capacity of the environment of rural areas,

- the stability of countryside ecosystems,

- the natural potential of the countryside,

- the functions served by a particular region (landscape).

Attempts to define the pattern of rural landscape optimization in reference books have been scarce so far and such articles have mainly addressed processes of changes in rural landscapes (Myga-Piątek 2010a, 2012) and their multiple functions (e.g. Healy, Short 2010, Falkowski 2014) or presented formalized algorithms or mathematical methods for assessing the level of landscape optimization (Grabaum Meyer 1998, Seppelt Voinov 2002, Bastian, Steinhardt 2002).

\section{Rural landscapes - unique heritage}

Besides the typical features of Poland's landscape, regional differences are still very clear; they mainly result from historical events of the late-18th and 19th centuries (the partitions of Poland), disrupted cultural continuity in many regions, radical changes in the land management model, different traditions of space management, different agricultural policies of occupying countries or, in post-war times, taking over the heritage of the Regained Territories and adapting them for the needs of the socialist economic model (Plit 2015).

The agrarian system introduced during the Partitions diversified the structure of rural landscapes in different regions of Poland, which can still be seen now in the spatial features of Greater Poland, Western Pomerania (within the Prussian Partition), Masovia, Polesie, Podlasie (the Russian Partition) and Lesser Poland, the Carpathians and the Carpathian Foothills (Galicia). Changes caused by political-legal-administrative decisions had the strongest impact, as they were often revolutionary (rapid) and have remained in rural landscapes until present times (Plit 2009, 
2015). Rural landscapes have recorded the effects of multiple land reforms (land subdivision or consolidation), granting property rights to peasantry, property nationalization etc. For example, there are field layouts in Podlasie which have remained since even more distant times, for example, since the land consolidation of the Volok Reform (starting in the times of Bona Sforza in the mid-16th century and continuing into the early 17th century during the reign of Sigismund Augustus) (Szewczyk 2008).

The most clearly and commonly preserved effects of land reforms come from the times of the socialist economy. The land reform introduced in Poland (then the Polish People's Republic) by the decree of 1944 was based on the collectivization of agriculture and increased share of the state sector with a reduced number of individual households. As a result of this reform, landed properties and large strong individual households vanished completely, as they were subdivided or taken over by the state. In those times, rural landscapes developed in conditions which saw intense growth in the mining and steelworking industries, especially in southern Poland, and "forced" modernization of the countryside. Apart from the unquestionable justification and need to facilitate life in the countryside (electrification of villages, construction of water supply pipelines, access to sales and service points), numerous unfavorable processes should be mentioned, which accompanied the rapid modernization of the Polish countryside. State Agricultural Farms (Polskie Gospodarstwo Rolne, PGR) established after 1949 introduced changes in the system of rural settlement. Villages were reconstructed, and former folwarks (great farms) and manor houses vanished to give way to a large settlement-service infrastructure, alienated from the landscape and creating a clear visual dissonance in relation to the historical tissue of the countryside. Two- or three-storey blocks of flats were built, as well as boiler houses with high chimneys and large outbuildings - barns, pigsties, stables, warehouses, sales pavilions made of metal, often within the area of former park-manor house or palace complexes (Myga-Piątek 2012, Machałek 2013). The post-war times started the processes marked by the loss of natural qualities of the countryside and landscape unification, which included chaotic management and the destruction of both tangible and intangible heritage - the traces of the old rich landed gentry tradition and manor house culture. Rural landscapes progressively lost their durable and harmonious character.

The collectivization process in agriculture was characteristic of central Europe in the late 20th century and concerned most socialist countries. By the end of the 1960s, $90 \%$ of households in Eastern Bloc countries had been collectivized. Poland was an exception among those countries, as collectivization was limited due to peasants' protests and a large part of cooperative farms created in the late 1940s broke up as soon as 1956 (Poczta et al. 2008). Private property of arable land remained in a large part of Poland. Cooperatives were mainly established in the western and northern territories, where all arable land was taken over by the state as post-German property and where the attachment of peasants to their land was much weaker (Machałek 2013, Markuszewska 2013).

Currently, rural landscapes in Poland are subject to further intense and unfavourable transformation. The processes of democratization in Poland, which started in the 1990s, were also applied in the case of spatial management. As a result of growing freedom in building and liberal legal regulations concerning spatial planning and agricultural use, rural landscapes underwent dynamic changes. The changes that could be noticed mainly consisted in abandoning agriculture, especially near large cities, in regions of small-area property or in regions with soils of low quality, and also in selling off land for various purposes, including recreational building - summer houses or housing estates, suburban investments - logistics-warehouses, service and municipal centres or construction of roads and highways. These processes are accompanied by ongoing secondary forest succession (field overgrowing), dispersion of settlement, and the loss of areas of sightseeing and aesthetic value in rural settlements. The spread of the urban building style and the disappearance of the traditional rural buildings style has resulted in the spread of suburban areas and the loss of the typical features of rural landscapes. As a consequence of these changes, landscapes are becoming closed (Plit, Myga-Piątek 2014). Moreover, changes in the intangible layer of the landscape are recorded as a result of vanishing regional 
identity, tradition, homeliness and individual, or even unique, features (Myga-Piątek 2010a, 2012, 2014). A model of highly industrialized production monoculture-type agriculture is being introduced within former large-scale properties and later State Farms (PGRs). Rural landscapes, which until recently composed a unique cultural heritage, a refuge of tradition and diversity, are undergoing spatial changes which result not only from globalization processes but also from typically Polish legal and mental conditions. These processes are registered in the form of landscape disharmonies and growing spatial chaos, which also translates into disruption to the ecological equilibrium.

The unfavourable processed presented above give an impulse for finding a template of rural landscape optimization based of the principles of a sustainable management model of the countryside.

\section{Landscape optimization in the light of the concept of sustainable development}

It has been shown above that the cultural landscape of rural areas is a distinctive cultural heritage. Treated as a special (limited) resource, it can be turned into an asset and play an important part in the strategy of sustainable development, both locally and nationwide. The value of the natural and cultural heritage provide potential and a basis for long-term regional development, and the sustainable management of this potential may facilitate landscape optimization.

In conditions of sustainable (harmonious) development, rural landscapes serve multiple functions for humans, the most important of which are production and residential functions; spatial, ecological, nature-protecting, recreational and aesthetic functions are also of great importance (Andrejczuk 2013a). Current adverse changes in rural landscapes consist in limiting their functions, which is an additional impulse for undertaking measures aimed at their optimization. Landscape optimization is a notion which was defined, among other sources, in the dictionary of notions related to landscape studies (Richling et al. 2015: 30). According to the entry in the dictionary, "landscape optimization consists in such human activity which is aimed at restoring the landscape equilibrium (or maintaining this state) and ensuring effective provision of various functions by landscape. It means choosing the best possible directions and methods of use of landscape resources according to the principles of sustainable development".

The definition of landscape optimization mentioned above includes the notion of "landscape equilibrium". This notion, as well as the whole definition, refers directly to the idea of sustainable development. The concept has been widely discussed in reference books (Pawłowski 2006, 2008, 2009, Skowroński 2006, Kronenber, Bergier 2010, Trzepacz 2012, among others), and has formed the foundation for concepts referring to particular issues related to development. One of those concepts refers to sustainable landscape and it seems to be particularly important in the context of the rapid changes to the Polish landscape described above.

Although the concept of sustainable development has been subject to extensive criticism in recent years (Skowroński 2006, Pawłowski 2007, Sztumski 2008, Redclift 2009, Kronenber, Bergier 2010, Wojtoń 2011, Andrejczuk 2013b, Nováček 2013), it is worth noting that it may not be treated as a creed which has to be accepted, but rather as an inspiration for testing new ideas, continuous experimenting, learning and searching for definite solutions. What also increases the importance of the concept of sustainable development is the fact that it has become commonly known, accepted and implemented. It is referred to by almost all national and international documents and it is a constitutional norm in Poland (1997 Journal of Laws, No. 78, item 483). The concept of sustainable development is a legal regulation in the European Union: all activities must be carried out in full accordance with the provisions of the concept. This concept is also referred to by the European Landscape Convention (2006 Journal of Laws, No. 14, item 98), which sets general rules for the landscape policy, and the act of 2015, which provided stringent measures for landscape conservation (2015 Journal of Laws, item 774).

The need for extended activities referring to the idea of sustainable development in the cultural landscape was pointed out by Myga-Piątek (2010b). Attempts to define sustainable landscape have been made by Haines-Young (2000), Antrop 
(2006), Kistowski (2008), Selman (2008) and Luc (2014), among others, and the processes of landscape optimization have been discussed by Grabaum and Meyer (1998), Seppelt and Voinov (2002), Bastian and Steinhardt (2002), Backhaus et al. (2002), Wiggering et al. (2006), Meyer et al. (2009), among other researchers, or, in relation to rural landscapes, by Hoffmann and Greef (2003) and Jessel (2006). Landscape equilibrium can be assessed through three basic levels of sustainable development: ecological, social and economic. The issue can also be extended to incorporate other aspects referring to the remaining levels of sustainable development (Pawłowski 2006): moral $^{1}$, technical, legal and political. The multiple dimensions of sustainable development suggest the interdisciplinary nature of the subject matter related to this concept, which may make the parametrization of the notion of sustainable landscape a task which is difficult to complete (Blaschke 2010) and requires the involvement of representatives of many scientific fields. Additionally, difficulties may arise from the assumption that landscape sustainability should be measured and assessed through the dynamics of the processes of change in the landscape rather than through its condition at any particular moment (Haines-Young 2000).

\section{Range of rural landscape optimization}

Several aspects of rural landscape optimization, referring to particular levels of sustainable development, may be distinguished by analyzing the evolution of rural landscapes in Poland (Fig. 1).

Ecological sustainability of rural landscape consists in use that takes into account the ecological capacity of the environment, the stability of ecosystems, the natural potential and the functions served by a given region. It is achieved by adjusting human activities within the landscape to its natural borders, enabling the harmonious coexistence of elements of the cultural landscape with the structure of the natural landscape. This natural landscape provides man with an

See paper: M. Luc, 2014, Placing the idea of sustainable landscape in ecophilosophy. Problems of Sustainable Development, vol 9, no 1, p. 81-88.

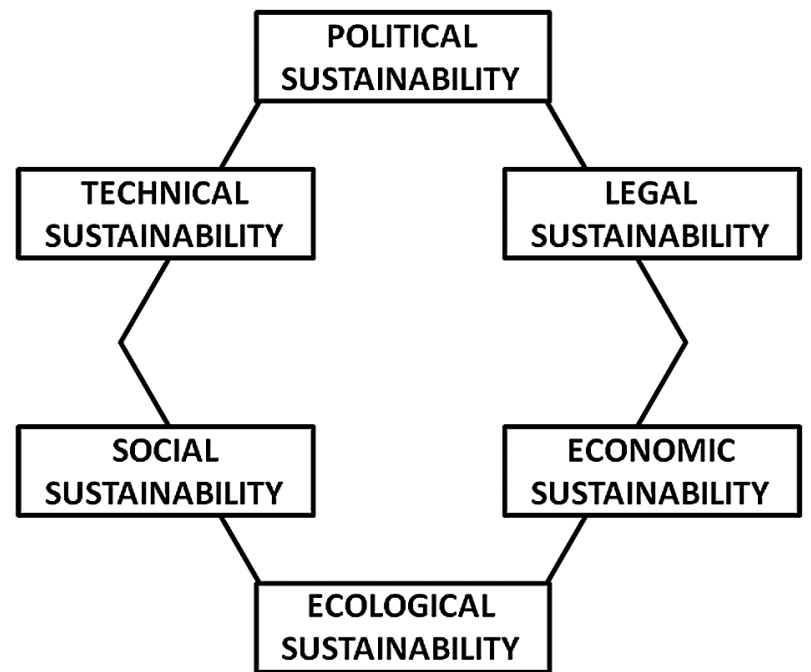

Fig. 1. Hexagonal diagram of conditions for landscape optimization.

opportunity to take up diverse activities, whose range depends on natural factors, population and human needs in a given area at a particular time (Andrejczuk 2013a). This adjustment can be assessed using analyses of the impact of natural factors on the structure of land management. Thorough assessment of natural conditions for the needs of agriculture might be carried out using the method developed by the Institute of Soil Science and Plant Cultivation in Puławy, which takes into account surface features, climatic conditions, water relations and soil cover (Głębocki 2007). The diversity of natural conditions in Poland results in the regional diversification of rural landscapes, characterized, among other things, by domination of permanent grassland in river valleys (e.g. the watershed of the Narew and the Biebrza) and in the Polesie Lubelskie region (a high level of ground water, periodic flooding), the Carpathians and the Sudetes (areas unsuitable for agriculture), orchard agriculture in the Kielce-Sandomierz Uplands and in the Lublin Uplands, corn cultivation in the Silesian Lowlands or legumes cultivation in the Lublin Uplands (favourable climatic conditions). Adjustment of land management to natural conditions is of great importance on a local level. This refers particularly to the ecological functions of tree clumps, swamps or reservoirs. Ecological sustainability is thus important for the ecological and nature-protecting functions of landscape.

Social sustainability of the landscape refers to meeting the needs and aspirations of the local 
community; thus, social participation is of importance in this case (Sobala 2014). The degree of this participation is still very low in Poland, which results from two aspects: little knowledge and awareness resulting from insufficient landscape education, as well as lack of an established custom (a duty, but also a right) of participation in social life. The low degree of participation of Poles in landscape management results from the negative heritage of the communism era, among other factors, and is a response to wider cultural, social and civilizational changes which are taking place. A low level of social involvement or little responsibility for the quality of the landscape is also determined by external global factors like consumptionism, poor-developed civic culture, the decreasing authority of the state and the diminishing sense of community (Olech, Sobiesiak-Penszko 2013). The chance for the social sustainability of landscapes can be seen, however, in the still strong emotional commitment of rural residents to the place they live (Pawłowska 2001, Jaśkiewicz 2009). With proper education and stimulation, it might contribute to increased social participation in landscape development (Mizgajski 2007). Thus, social sustainability is essential for serving the spatial function (living space), as well as the recreational, aesthetic and educational ones. Many valuable initiatives, whose aim is landscape planning with social participation, are already being developed in that regard (Blomberg, Fidler 2013).

Economic sustainability of the landscape is assessed on the basis of economic calculations taking into account the mechanisms which support business activities. The economics of management is influenced by the agrarian structure (in terms of size and property) of agriculture, the employment pattern (employment rate and level of education) and methods of management. Insufficient revenue from agricultural activities fosters individual non-agricultural businesses. The number of farmstead owners who only depend on agricultural production is falling; many also earn money from work outside their farms (Krakowiak-Bal 2009). As in the 1970s and 1980s, when the position of temporary farm worker was popular in the countryside near larger urban agglomerations, employment of countryside residents outside agriculture is also currently growing. The proportion of the population with agriculture as their main source of income dropped by $4 \%$ between 2002-2011, and only $6.38 \%$ of the rural population declared farming to be their sole source of income in 2011 (Nurzyńska 2014). The need for the rural population to seek various sources of income when agricultural production appeared to be insufficient gave rise to the concept of the multifunctional development of the countryside (Adamowicz, Zwolinska-Ligaj 2009). Traditional rural areas served multiple functions, but the land reform of 1944 mostly reduced the functions of the countryside to production and food provision. As early as the mid1970s, Kostrowicki (1976) pointed to the need for developing non-agricultural functions of the countryside. Large-scale diversification of rural landscapes, resulting from different histories and distinct patterns of socio-economic development and natural conditions, requires the appropriate specialization of particular regions along with the rational use of local natural conditions, natural and man power resources, which may result in the increased efficiency of management. Such specialization may be based on developing the whole range of rural functions, such as farming, forestry, fishery, recreation, food processing and services for local residents and visitors. The development of various functions may be followed by optimization of the rural landscape resulting from the diversification of business activities adjusted to local conditions. An appropriate combination of those functions is the determinant of optimization (Andrejczuk 2013a).

Agricultural activities can also satisfy multiple needs: environmental, cultural, economic and social ones. Farming may be regarded not only as a provider of food products, which are essential for human existence, but also as a producer of foods and services which are not marketable but are of great importance for man and the environment (Table 1).

Implementation of particular practical solutions determines the next three areas of landscape sustainability. Methods of management, including mechanization, land improvement, fertilization, and crop rotation as well as the care and protection of crops from diseases and pests have an impact on technical sustainability. This is directly related to the state's farming policy, which determines the level of political sustainability. Referring to Poland, it should be 
Table 1. Classification of commercial and non-commercial functions of agriculture, acc. Wilkin (2010: 65).

\begin{tabular}{|c|c|c|c|}
\hline Productive functions & Social functions & Cultural functions & Environmental functions \\
\hline $\begin{array}{l}\text { - commercial: food prod- } \\
\text { ucts, farming commodi- } \\
\text { ties, agricultural products } \\
\text { for energy production, } \\
\text { tourist services related to } \\
\text { agriculture; } \\
\text { - non-commercial: self-pro- } \\
\text { vision of household with } \\
\text { food, self-made means } \\
\text { of production for own } \\
\text { needs. }\end{array}$ & $\begin{array}{l}\text { - impact on economic } \\
\text { stability and social integ- } \\
\text { rity of the countryside, } \\
\text { element of social support } \\
\text { for farming families and } \\
\text { some of non-farming } \\
\text { families, stabilizer of } \\
\text { shock caused by eco- } \\
\text { nomic and institutional } \\
\text { changes. }\end{array}$ & $\begin{array}{l}\text { - protection and enhance- } \\
\text { ment of cultural tradi- } \\
\text { tions in the countryside, } \\
\text { enhancement of national } \\
\text { culture, strengthening } \\
\text { cultural identity and } \\
\text { diversity locally and } \\
\text { regionally, development } \\
\text { of cultural capital, protec- } \\
\text { tion and enhancement of } \\
\text { cultural landscape in the } \\
\text { countryside. }\end{array}$ & $\begin{array}{l}\text { - negative: soil and water } \\
\text { pollution with chemicals } \\
\text { and municipal waste, } \\
\text { soil erosion, decreased } \\
\text { biodiversity of agricul- } \\
\text { tural land, emission of } \\
\text { greenhouse gases } \\
\text { - positive: preventing en- } \\
\text { vironmental degradation } \\
\text { of arable land, protec- } \\
\text { tion of biodiversity of } \\
\text { farming areas, protection } \\
\text { or improvement of water } \\
\text { conditions in farming } \\
\text { areas, prevention of soil } \\
\text { erosion. }\end{array}$ \\
\hline
\end{tabular}

emphasized that the last two decades have been a phase of radical reforms in agriculture. After 1989, as a result of the collapse of communism, a centrally planned economy was replaced with a market economy associated with the radical restructuring process. In 2004 Poland's accession to the European Union made it possible for Polish farmers to make use of financial support connected with the Common Agricultural Policy (CAP) (Markuszewska 2013). This policy is a major driver of land use and changes in farming practices in Europe, and thus also affects landscapes. Overall, the influence of the CAP on landscapes is multifaceted. On one hand, the CAP is acknowledged to have contributed to the modernisation of European agriculture and its intensification, which was translated into landscape homogenization, by the rationalisation of farm's size and structure, and the consequent loss of many traditional features. On the other hand, through direct payments and the Less Favoured Area scheme, the CAP has promoted maintenance of the status quo with respect to the continuation of farming in marginal areas, and more specifically, the preservation of extensive grazing systems, therefore contributing to the conservation of traditional rural landscapes, avoiding land abandonment and the disappearance of these landscapes. Moreover, the necessity to comply with good agricultural and environmental standards in order to receive the full decoupled direct payment, and the implementation of agri-environmental payment schemes to encourage farmers to carry out agricultural activities favourable to the maintenance of the countryside has positively influenced landscape provision (Lefebvre et al. 2012). The current legislative system, having a real impact on landscape development, determines the conditions for legal sustainability. The Act of 24 April 2015 amending certain acts in connection with the strengthening of landscape protection tools (2015 Journal of Laws, item 774) provides for increased protection of only selected landscapes, which are referred to as priority landscapes. Other types of landscape are to be subject to legal regulations currently in force. With an imperfect system approach to landscape conservation, resulting, among other factors, from the fact that local plans of spatial planning are only optional rather than mandatory, legal foundations for landscape conservation are scattered in multiple acts and executive instruments for protection are poorly developed, there is a real concern regarding very unfavourable changes to Poland's rural landscape (Śleszyński et al. 2007, Böhm 2008, Badora 2014, Fogel 2014, Fogel 2015, Myga-Piątek, Nita 2015, Wańkowicz 2015). On the other hand, numerous academic and social initiatives regarding landscapes ${ }^{2}$ created a favourable climate for putting all activities relating to landscape policy in order and optimizing landscape management. One of the most valuable initiatives is the countryside restoration programme, which has been implemented successfully in many provinces (Wilczyński 2003, Niedźwiecka-Filipiak, Kuriata 2010).

2 Publications and conference materials by the Commission of Cultural Landscape of the Polish Geographical Society or by the Association of Polish Architects should be mentioned here. 


\section{Factors of rural landscape optimization}

The regional diversity of rural landscapes in Poland is characterized by still high values of natural and cultural heritage (Plit 2015). It offers potential for the development of rural regions and may determine their specialization. Many different factors should be taken into consideration in an integrated way when planning rural landscape optimization (Table 2).

The factors distinguished refer to areas of sustainable development. It should be noted that the first group of factors is objective in character and exists independently of the will, views or

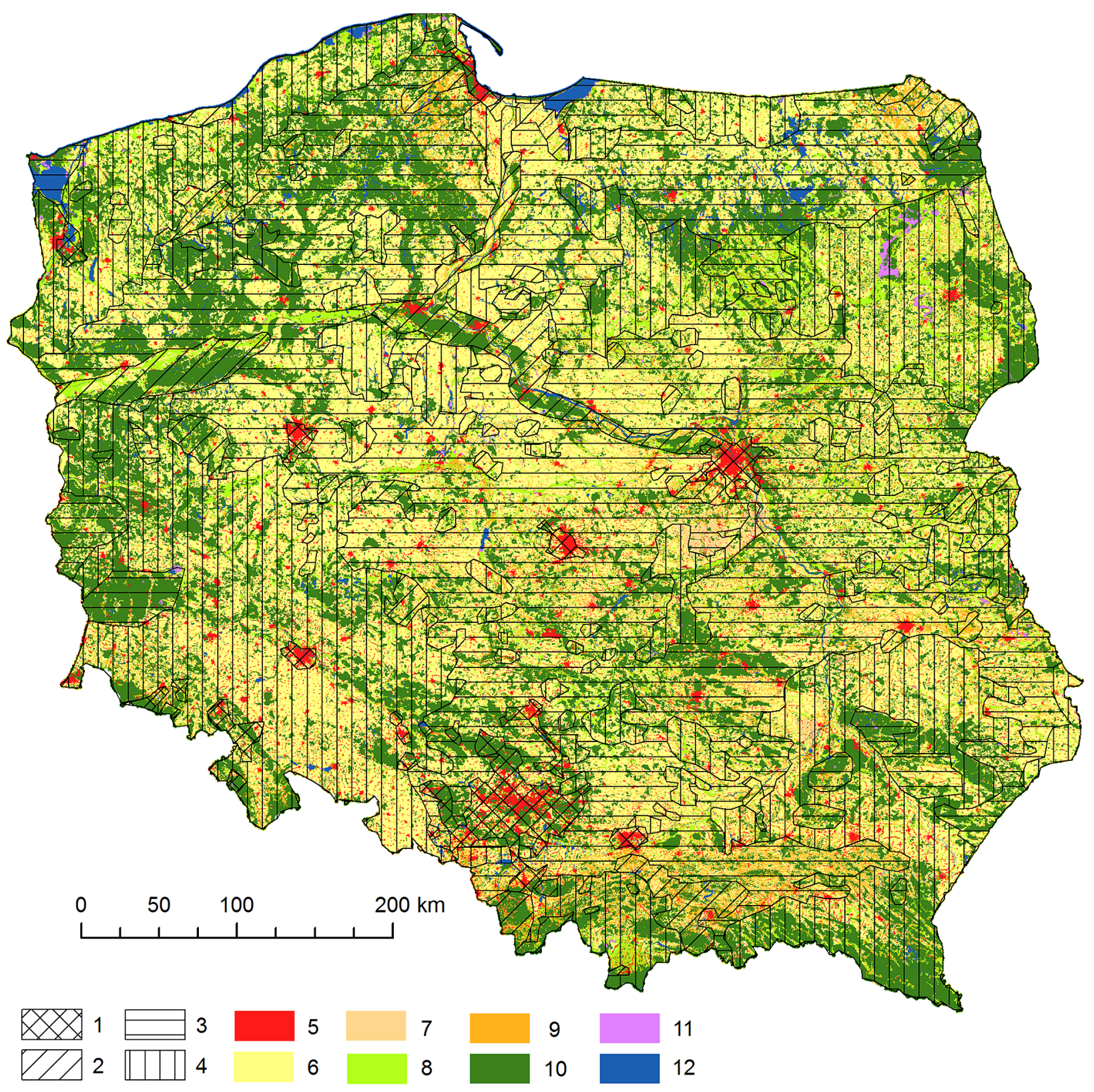

Fig. 2. Spatial diversity of rural landscape types in terms of settlements types and land cover on the basis of Corine Land Cover 2006, Kiełczewska-Zalewska (1965) and Szymańska (2009) (author's generalization).

1 - landscapes of urban settlements; 2 - landscapes of rural settlements primary distributed, with the lowest degree of concentration, in swamps, sandrs and secondary distributed; 3 - mixed landscape of rural settlements

with a dash distributed; 4 - landscape of rural settlements - focused, with elongated buildings and with a predominance of linear settlement; 5 - artificial surfaces; 6 - arable land; 7 - permanent crops; 8 - pastures; 9 heterogeneous agricultural areas; 10 - forest and seminatural areas; 11 - wetlands; 12 - water bodies. 
Table 2. Important factors for planning rural landscape optimization.

\begin{tabular}{|l|l|}
\hline \multicolumn{1}{|c|}{ Factors } & \multicolumn{1}{c|}{ Description } \\
\hline natural & $\begin{array}{l}\text { potential and actual directions of use of natural resources and values, methods and } \\
\text { level of optimum management of natural resources, character of ecological processes, } \\
\text { ecological structure of landscape (occurrence of tree clumps, ponds, forest patches, } \\
\text { baulks), ecological threats to human activities, including soil erosion, level and need } \\
\text { for nature protection, including preservation of traditional agriculture, trans-regional } \\
\text { environmental relations (ecological corridors) }\end{array}$ \\
\hline historical-cultural & $\begin{array}{l}\text { degree of preservation of characteristic field layout, clarity of the morphological types } \\
\text { of villages, architectural regionalism, lifestyles and values, regional identity, cultural } \\
\text { level, cultivation of tradition }\end{array}$ \\
\hline social & $\begin{array}{l}\text { character and method of administration by local authorities and level of social support } \\
\text { for authorities, social participation, demographic phenomena }\end{array}$ \\
\hline economic & $\begin{array}{l}\text { transition into market-oriented economy, capital resources, demand, profitability of } \\
\text { business activities, traditional methods of management, income of residents, employ- } \\
\text { ment pattern, workplaces, mutual relations between regions, neighbourhood of urban } \\
\text { centres, degree of use of resources from EU programmes }\end{array}$ \\
\hline political & $\begin{array}{l}\text { strategies of action for environment related to occurrence of areas degraded as a result } \\
\text { of improper agriculture or regions with high values requiring protection, conflicts } \\
\text { between business, social or political objectives and those related to nature protection }\end{array}$ \\
\hline legal & $\begin{array}{l}\text { current legal regulations, existing forms of landscape protection, quality of spatial } \\
\text { planning }\end{array}$ \\
\hline technical and technological & $\begin{array}{l}\text { technical and technological level, level and directions of innovation, methods of man- } \\
\text { agement in agriculture: work mechanization, land improvement, use of natural and } \\
\text { artificial fertilizers, crop rotation, care and protection from diseases and pests }\end{array}$ \\
\hline
\end{tabular}

approaches of landscape users. Analysis of the natural conditions of human activities allows the ecological equilibrium of landscape to be determined. The remaining factors are relative and depend on perception, expressed values, attitudes, needs, economic conditions, current legal regulations of the level of technological development. Landscape optimization, based on sustainable development principles, may also be enabled by controlling relative factors in a way which will result in ecological equilibrium of landscape, guaranteeing its durability and a high quality of life.

As natural-cultural and cultural landscapes are predominant in Poland (Chmielewski et al. 2015), historico-cultural factors are also important for their optimization. As a result of the influence of these factors, rural landscapes have been enhanced in the process of their evolution with distinguishing features which currently emphasize their specificity and distinctness (Myga-Piątek et al. 2015). There are differences in the structure and morphology of rural settlements as well as in the average size of fields between particular regions of Poland. It allows different types of rural landscapes to be distinguished (Fig. 2, 3). The growing importance of external landscape-forming factors (economic situation, globalization processes, techno-civilizational growth) contributes to the unification of rural landscapes and causes them to become landscapes at a distance (Vos, Meekes 1999). In order to achieve the sustainable development of landscapes, it is necessary to increase the importance of external factors, which may not only be favourable for preserving the value of Polish rural landscapes, but also facilitating the competitiveness of particular regions and, consequently, the quality of life.

\section{Summary}

Rural landscapes in Poland, like in many other regions of the world, are currently undergoing intense transformation resulting mainly from the influence of external factors related, among other things, to changing lifestyles and increased mobility of the society. This transformation is accompanied by functional changes in rural areas and the increased importance of their non-agricultural functions. These are mostly negative processes and are reflected in Poland's rural landscapes, which threatens their sustainable development. As a result, a need arises to find a pattern of optimization and solutions which would make it 


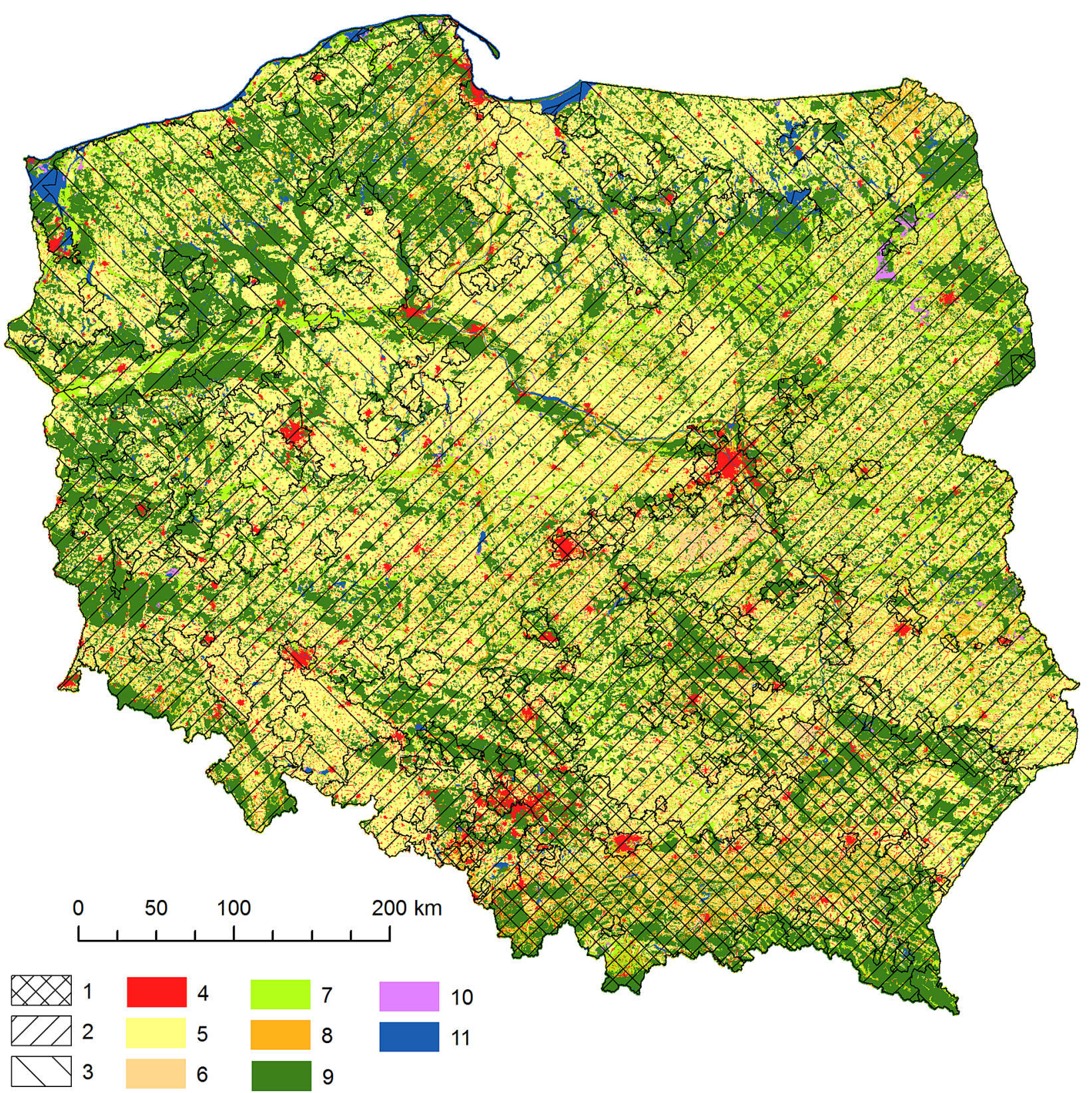

Fig. 3. Spatial diversity of rural landscape types in terms of field size and land cover on the basis of Corine Land Cover 2006 and Głębocki (2014) (author's generalization).

1 - rural landscapes with the predominance of small fields of agricultural land (the average size of agricultural holding below $5 \mathrm{ha}$ ); 2 rural landscapes with the predominance of medium fields of agricultural land (the average size of agricultural holding 5-20 ha); 3 - rural landscapes with the predominance of large fields of agricultural land (the average size of agricultural holding above $20 \mathrm{ha}$ ); 4 - artificial surfaces; 5 - arable land; 6 - permanent crops; 7 - pastures; 8 - heterogeneous agricultural areas; 9 - forest and seminatural areas; 10 wetlands; 11 - water bodies.

possible to work out and implement the principles of sustainable management in rural regions (Vos, Meekes 1999).

The matter of sustainable development of landscapes can be addressed in two ways (Antrop 2006). Firstly, through preserving some values of landscapes by continuing activities which contributed to the creation of those values. In the case of rural landscapes, this mainly concerns agriculture. Sadly, landscape-forming is still poorly supported by farming policy, development policy for rural regions, or nature protection measures. These actions are often taken up and treated separately, while the natural and 
cultural environments of rural regions have always been closely related. Thus, it is essential for the sustainable development of rural landscapes to maintain certain types of agricultural activities and to work out successful and effective ways of public support (controlling relative factors). On the other hand, landscape optimization may be referred to as the preservation of its equilibrium by introducing completely new landscape functions, while being able to maintain the values existing so far. Polish rural landscapes, which have so far been little exposed (promoted) to international tourist traffic, have great development potential in terms of agrotourism, ecotourism, sightseeing and ecological agriculture. Such an approach, however, requires abstaining from a strictly economic attitude (tourism commercialization and intensification of economic profits).

The development directions of particular rural regions may vary due to the extremely diverse nature of rural landscapes. They should be individualized and refer to the natural and historico-cultural potential of regions. Each optimization model should be determined individually for a particular landscape. Setting the direction of their optimization according to the principle of sustainable development requires controlling relative factors in a way which will lead to the ecological equilibrium of the landscape, guaranteeing its durability and a high quality of life.

\section{References}

Adamowicz M., Zwolińska-Ligaj M., 2009. Koncepcja wielofunkcyjności jako element zrównoważonego rozwoju obszarów wiejskich (The concept of multifuncionality as an element of sustainable development of rural areas). Zeszyty Naukowe SGGW 2(51): 11-38.

Andrejczuk W., 2013a. Funkcje krajobrazu kulturowego (Cultural landscape functions). Dissertations of Cultural Landscape Commission 20: 65-81.

Andrejczuk W., 2013b. Koncepcje współdziałania człowieka i natury w krajobrazie (Concepts of interaction between man and nature in landscape). Dissertations of Cultural Landscape Commission 20: 9-16.

Angiel M., Pietrzak M., 2009. Wieś tradycyjna w krajobrazie pogórzy karpackich (Traditional village in landscape of the Carpathian Foothills). Dissertations of Cultural Landscape Commission 12: 13-22.

Antrop M., 2006. Sustainable landscapes: contradiction, fiction or utopia? Landscape and Urban Planning 75: 187-197. DOI: 10.1016/j.landurbplan.2005.02.014.

Backhaus R., Bock M., Weisers S., 2002. The spatial dimension of landscape sustainability. Environment.
Development and Sustainability 4(3): 237-251. DOI: 10.1023/A:1021138602157.

Badora K., 2014. Spatial system of landscape protection in Poland. Dissertations of Cultural Landscapes Commission 23: 73-88.

Bański J., 2009. Historia rozwoju gospodarki rolnej na ziemiach polskich (History of agricultural development in Poland). In: Górka Z., Zborowski A. (eds), Cztowiek i rolnictwo. IGiPZ Uniwersytet Jagielloński, Kraków: 33-45.

Bastian O., Steinhardt U., 2002. Development and perspectives of landscape ecology. Kluwer Academic, Dordrecht.

Blaschke T., 2010. Sustainable Landscapes - Regionalization of Resources, Potentials and Demands. In: Buhmann E., Pietsch M., Kretzler E. (eds), Peer-reviewed proceedings of Digital Landscape Architecture 2010. Wichmann, Heidelberg: 341-350.

Blomberg P., Fidler K., 2013. Podręcznik planowania krajobrazu $z$ partycypacja spoteczna. Lifescape, Implementing European Landscape Convention in the South Baltic Region. Elblacg.

Bogdanowski J., 1998. Konserwacja i ochrona krajobrazu kulturowego (ewolucja metody). Teki krakowskie VI, Regionalny Ośrodek Studiów i Ochrony Środowiska, Kraków.

Böhm A., 2008. Między mandatem a partycypacją społeczną (Between the mandatory and public participation). Dissertations of Cultural Landscapes Commission 10: 515-524.

Chmielewski T.J., Myga-Piątek U., Solon J., Kistowski M., 2015. Typologia aktualnych krajobrazów Polski (Typology of Poland's current landscapes). Przeglad Geograficzny 87(3): 377-408.

Constitution of the Republic of Poland of 2nd April 1997 (Journal of Laws from 1997 No. 78, item 483).

European Landscape Convention (Journal of Laws from 2015, No 14, item 98).

Falkowski J., 2014. Wielofunkcyjność i próba wyróżnienia funkcjonalno-gospodarczych typów krajobrazu wiejskiego Polski (Multifunctionality and Attempt to Define Functional and Economic Types of Rural Landscapes in Poland). Studia Obszarów Wiejskich 35: 9-29.

Fogel A., 2014. Uwarunkowania prawnoustrojowe ochrony i kształtowania krajobrazu (Legal and Systemic Conditions for Protecting and Shaping the Landscape). Samorzad Terytorialny 228(12): 44-54.

Fogel A., 2015. Ustawa krajobrazowa. Komentarze praktyczne. Wolters Kluwer, Warszawa.

Głębocki B., 2007. Rolnictwo (Agriculture). In: Rogacki H. (ed.), Geografia spoteczno-gospodarcza Polski. Wyd. Nauk. PWN, Warszawa: 185-271.

Grabaum R., Meyer B.C., 1998. Multicriteria optimization of landscapes using GIS-based functional assessments. Landscape and Urban Planning 43: 21-34.

Healy R.G, Short J.L., 2010. The Changing Rural Landscape. Environment: Science and Policy for Sustainable Development 23(10): 6-34. DOI: 10.1080/00139157.1981.9928763.

Hoffmann J., Greef J.M., 2003. Mosaic indicators - theoretical approach for the development of indicators for species diversity in agricultural landscapes. Agriculture, Ecosystems and Environment 98(1-3): 387-394. DOI: 10.1016/ S0167-8809(03)00098-7.

Haines-Young R., 2000. Sustainable development and sustainable landscape: defining new paradigm for landscape ecology. Fenia 178(1): 7-14.

Jaśkiewicz A., 2009. Małe ojczyzny - poczucie przynależności Polaków. Komunikat z badań, CBOS.

Jessel B., 2006. Indicators and assessment of multifunctionality - operationalising the concept for planning applica- 
tions in landscapes. In: Meyer B.C. (ed.), Sustainable land use in intensively used agricultural regions 1338. Landscape Europe, Wageningen: 36-47.

Kiełczewska-Zalewska M., 1965. O typach osiedli wiejskich w Polsce i planie ich przebudowy (On types of rural settlement network and its transformation). Przeglad Geograficzny 37(3): 457-480.

Kistowski M., 2008. Koncepcja równowagi krajobrazu - mity i rzeczywistość (The concept of landscape sustainability - myths and reality). The Problems of Landscape Ecology 21: 81-91.

Kostrowicki J., 1976. Obszary wiejskie jako przestrzeń wielofunkcyjna. Zagadnienia badawcze i planistyczne. Przeglad Geograficzny 48(4): 607-608.

Krakowiak-Bal A., 2009. Pozarolnicza działalność gospodarcza polskich gospodarstw rolniczych na tle gospodarstw z krajów Unii Europejskiej (Other gainful activity in agricultural holdings in Poland and EU countries). Infrastruktura i Ekologia Terenów Wiejskich 5: 209-217.

Kronenber J., Bergier T., 2010. Wyzwania zrównoważonego rozwoju w Polsce. Fundacja Sendzimira, Kraków.

Lefebvre M., Espinosa M., Gomez y Paloma S., 2012. The influence of the Commone Agricultural Policy on agricultural landscapes. JRC Scientific and Policy Report, European Commission, Joint Research Centre, Institute for Prospective Technological Studies, Seville.

Luc M., 2014. Placing the idea of sustainable landscape in ecophilosophy. Problems of Sustainable Development 9(1): 81-88.

Machałek M., 2013. Przemiany polskiej wsi w latach 19181989 (Changes in the Polish countryside in the years 1918-1989). Klio 26(3): 55-80.

Markuszewska I., 2013. Changes of agricultural landscape pattern - non-natural driving forces analyzing based on the North-Western region of Poland. Quaestiones Geographicae 32(1): 5-14. DOI: 10.2478/quageo-2013-0001.

Meyer B.C., Lescot J.M., Laplana R., 2009. Comparison of Two Spatial Optimization Techniques: A Framework to Solve Multiobjective Land Use Distribution Problems. Environmental Management 43: 264-281. DOI: 10.1007/ s00267-008-9225-0.

Mizgajski A., 2007. Development of rural landscape in Wielkopolska in reference to metabolism of agroecosystems. Quaestiones Geographicae 26A: 39-51.

Myga-Piątek U., 2010a. Directions and prospects of transformation in cultural landscapes of Poland - considerations and attempts of evaluation. Acta Geographica Debrecina, Landscape E Environment Series 4(2): 45-58.

Myga-Piątek U., 2010b. Przemiany krajobrazów kulturowych w świetle idei zrównoważonego rozwoju (Transformation of the cultural landscapes in the light of the idea of sustainable development). Problems of Sustainable Development 5(1): 95-108.

Myga-Piątek U., 2012. Krajobraz kulturowy. Aspekty ewolucyjne $i$ typologiczne (Cultural landscapes. Evolutionary and typological aspects). Wyd. Uniwersytet Śląski, Katowice.

Myga-Piątek U., 2014. Ocena wartości i zagrożeń krajobrazów kulturowych Polski. Perpsektywa Europejskiej Konwnecji Krajobrazowej (Assessment of the Value of and Threats to Poland's Cultural Landscape. Perspective of the European Landscape Convention). Samorzad Terytorialny 288(12): 7-19.

Myga-Piątek U., Nita J., 2015. Polityka krajobrazowa Polski - u progu wdrożeń (Landscape policy of Poland - The initial stage of implementation). Przeglad Geograficzny 85(1): 5-25.

Myga-Piątek U., Chmielewski T.J., Solon J., 2015. Rola cech charakterystycznych, wyróżników i wyznaczników krajobrazu w klasyfikacji i audycie krajobrazów aktualnych (The role of characteristic features, landmarks and determinants in classification and audit of the current landscapes). The Problems of Landscape Ecology 40: 177-185.

Niedźwiecka-Filipiak I., Kuriata Z., 2010. Architektura krajobrazu w programie odnowy wsi opolskiej. Wydawnictwo Uniwersytetu Przyrodniczego we Wrocławiu, Wrocław.

Nováček P., 2013. After Rio+20; Preparing for sustainable retreat? Quaestiones Geographicae 32(1): 55-60. DOI: 10.2478/quageo-2013-0007.

Nurzyńska I., 2014. Przemiany struktury gospodarki wiejskiej. In: Nurzyńska I., Poczta W. (eds), Polska wieś 2014. Raport o stanie wsi. Wyd. Naukowe Scholar: 125-152.

Olech A., Sobiesiak-Penszko P., 2013. Partycypacja publiczna w Polsce. Diagnoza i rekomendacje. Analizy i Opinie 3: $1-24$.

Pawłowska K., 2001. Idea swojskości krajobrazu kulturowego. In: Myga-Piątek U. (ed.), Krajobraz kulturowy - idee, problemy, wyzwania. WNoZ, Sosnowiec: 95-100.

Pawłowski A., 2006. Wielowymiarowość rozwoju zrównoważonego (The multidimensional nature of sustainable development). Problems of Sustainable Development 1(1): 23-32.

Pawłowski A., 2007. Bariery we wdrażaniu rozwoju zrównoważonego - spojrzenie ekofilozofa (Barriers in introducing sustainable development - ecophilosophical point of view). Problems of Sustainable Development 2(1): 59-65.

Pawłowski A., 2008. Rozwój zrównoważony - idea, filozofia, praktyka. Monografie Komitetu Inżynierii Środowiska PAN 51, Lublin.

Pawłowski A., 2009. Rewolucja rozwoju zrównoważonego (The Sustainable Development Revolution). Problems of Sustainable Development 4(1): 65-76.

Plit J., 2009. Ocena przemian sposobu użytkowania ziemi na Ziemi Sławieńskiej w świetle koncepcji rozwoju zrównoważonego (Assessment of change in use lands on sławieński region in the light of the concept of sustainable development). In: Jacewicz I. (ed.), Wspótczesne problemy przemian struktury przestrzeni geograficznej. Słupsk: 154168.

Plit J., 2015. Przestrzenne zróżnicowanie i cechy charakterystyczne krajobrazów Polski w ujęciu historyczno-kulturowym (Historic-cultural approach to spatial differentiation and characteristic features of Polish landscapes). The Problems of Landscape Ecology 40: 113-134.

Plit J., Myga-Piątek U., 2014. The degree of landscape openness as a manifestation of cultural metamorphoses. Quaestiones Geographicae 33(3): 145-154.

Poczta W., Sadowski A., Średzińska J., 2008. Rola gospodarstw wielkotowarowych w rolnictwie Unii Europejskiej (The role of the large-scale production farm in the European Union agriculture). Roczniki Nauk Rolniczych G 95(1): 42-56.

Redclift M.R., 2009. Rozwój zrównoważony (1987-2005) oksymoron czasu dorastania (Sustainable Development (1987-2005) - an Oxymoron Comes of Age). Problems of Sustainable Development 4(1): 33-50.

Richling A., Andrejczuk V., Ruderko L., Czechnij W., 2015. Stownik polsko-ukraiński oraz ukraińsko-polski podstawowych 
terminów i pojęć z zakresu nauki o krajobrazie. Wydawnictwo PSW JP II, Biała Podlaska.

Selman P., 2008. What do we mean by sustainable landscape? Sustainability: Science, Practice, \& Policy 4(2): 23-28.

Seppelt R., Voinov A., 2002. Optimization methodology for land use patterns using spatially explicit landscape models. Ecological Modelling 151: 125-142

Skowroński A., 2006. Zrównoważony rozwój perspektywą dalszego postępu cywilizacyjnego (Sustainable development as the perspective of further civilisation development). Problems of Sustainable Development 1(2): 47-57.

Sobala M., 2014. Contemporary Views on Social Participation in the Context of Sustainable Development of Rural Landscapes. Dissertations of Cultural Landscapes Commission 23: 135-147.

Sobala M., 2015. Optymalizacja użytkowania ziemi w obrębie wybranych krajobrazów kulturowych Beskidu Śląskiego i Żywieckiego. Rozprawa doktorska, Archiwum Wydziału Nauk o Ziemi UŚ, Sosnowiec (maszynopis).

Szewczyk J., 2008. Przemiany krajobrazu na Białostocczyźnie (Landscape changes in Białystok region). Dissertations of Cultural Landscapes Commission 10: 256-266.

Sztumski W., 2008. Refleksja na temat rozwoju zrównoważonego. Czy rozwój zrównoważony jest fikcją, utopią, iluzją czy oszustwem? (Reflection about sustainable development. Is sustainable development fiction, utopia, illusion of swinndel?). Problems of Sustainable Development 3(2): 133-139.

Szymańska D., 2009. Geografia osadnictwa. Wyd. Nauk. PWN, Warszawa.
Śleszyński P., Bański J., Degórski M., Komornicki T., Więckowski M., 2007. Stan zaawansowania planowania przestrzennego $\mathrm{w}$ gminach (Progress of spatial planning in gminas). Prace Geograficzne 211.

Trzepacz P., 2012. Zrównoważony rozwój - wyzwania globalne. IGiGP UJ, Kraków.

The Act on 24th of April 2015 on changes in some acts in connection with the reinforcement of landscape protection tools (Journal of Laws from 2015, item 774).

Vos W., Meekes H., 1999. Trends in European cultural landscape development: perspectives for a sustainable future. Landscape and Urban Planning 46: 3-14.

Wilkin J., 2010. Wielufunkcyjność rolnictwa. Kierunki badań, podstawy metodologiczne $i$ implikacje praktyczne. IRWiR PAN, Warszawa.

Wańkowicz W., 2015. Prawne podstawy zarzadzania krajobrazem. Instytut Architektury Krajobrazu, Politechnika Krakowska, Kraków.

Wilczyński R., 2003. Odnowa wsi perspektywa rozwoju obszarów wiejskich w Polsce. Fundacja Fundusz Współpracy. Program Agro-Info, Poznań.

Wiggering H., Dalchow C., Glemnitz M., Helming K., Mueller K., Schultz A., Stachow U., Zander P., 2006. Indicators for multi-functional land use - linking socio-economic requirements with landscape potentials. Ecological Indicators, 6(1): 238-249.

Wojtoń M., 2011. Zrównoważony rozwój - mit stworzony przez polityków czy narzędzie ratujące pokolenia przed ekologiczną katastrofą? In: Jamczura T., Kretek H. (eds), Zrównoważony rozwój - debiut naukowy 2010. Wydawnictwo PWSZ, Racibórz: 58-67. 